\title{
EDITOR'S ACKNOWLEDGEMEN'TS
}

In the first place I should like to acknowledge my debt to Professor D. C. Douglas's volume of Feudal Documents from the Abbey of Bury St. Edmunds which covered the period from 1066 to II82. The present volume continues the series of documents from II 82 to I2II, and it will be obvious that it could not easily have been compiled without the assistance of the earlier work.

I should also like to thank all those who have helped me, even though it is impossible to name them all. Special mention, however, must be made of Mr. G. W. S. Barrow, who read through the greater part of the proofs, and of Professor H. M. Cam and Mr. R. W. Southern for timely advice and criticism at an early stage of the work. The greatest debt of all is to Professor V. H. Galbraith, who drew my attention to the Kalendar, encouraged me to study it, allowed me free use of his transcript of it, and finally contributed the Foreword to this volume. I wish only that I could have repaid such generosity with a more perfect edition.

Since this volume went to press, two further original charters of Abbot Samson have been brought to my notice. The first (Fitzwilliam Museum, Cambridge, MS. 328) is the original of charter 26 and has the seal of the abbey in wax. Apart from some variant spellings, especially of place-names, the text and list of witnesses are as printed on pp. 89-9o. The second (British Museum, MS. Egerton 2180), not printed here, is reproduced in facsimile in the British Museum Quarterly, xi. 62-3. It is a grant to Robert de Braybrooke of 2 virgates in Braybrooke (Northants) and is sealed with the seals of both Abbot Samson and the convent (probably c. I208-II).

R. H. C. D. 